ARID International Journal of Social Sciences and Humanities (AIJSSH) VOL.2, Special Issue (1), August 2020

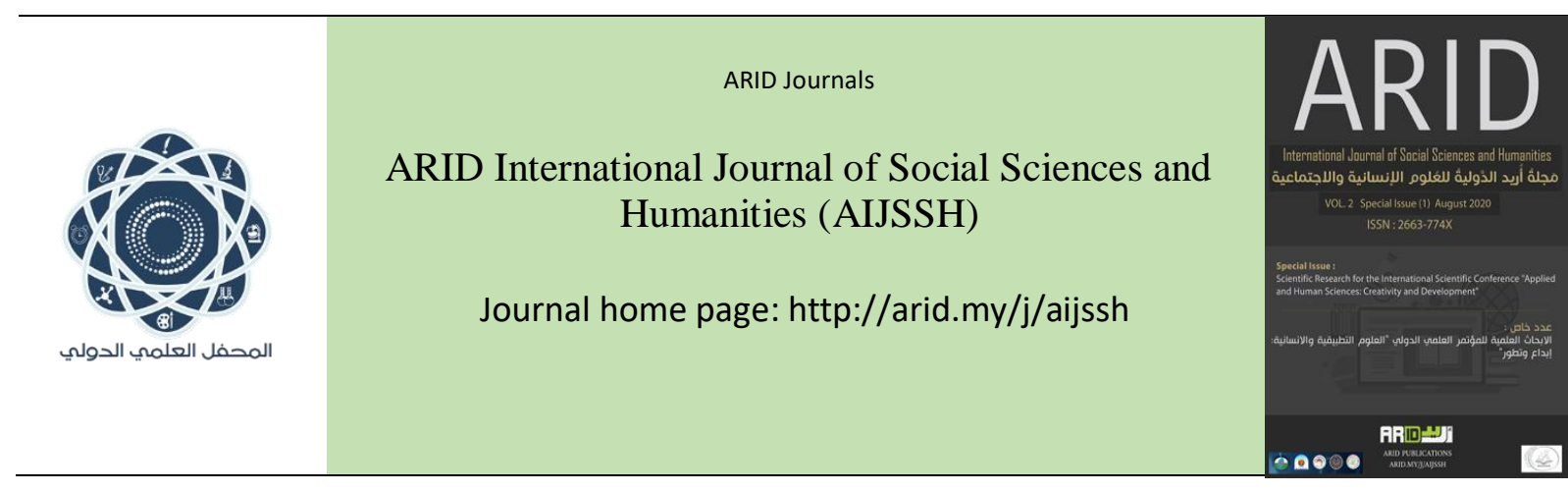

$$
\begin{aligned}
& \text { مَجلةُ أُريد الدَّوليةُ للعُلومر الإنسانية والإجتماعية } \\
& \text { المجلد الثاني ،العدد الخاص ، آب } 2020 \text { م }
\end{aligned}
$$

\title{
Universities and their role in promoting democratic values
}

$$
\text { م.د. منتصرحسين جو اد* }
$$

07804457592m@gmail.com arid.my/0004-5782

https://doi.org/10.36772/arid.aijssh.2020.s.2111 


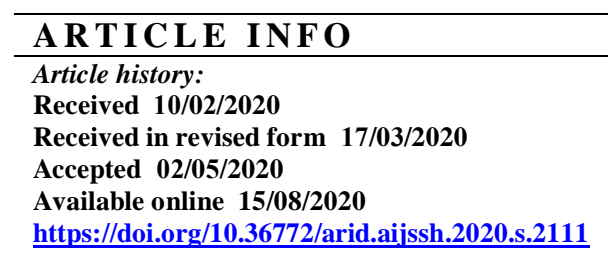

\begin{abstract}
The university environment plays an important role in the consolidation of democratic values and human behavior, and it is entrusted with the task of shaping youth with thought, action and conscience. The research aims at the role of the university environment in promoting and developing democratic values, so we find an important link between the university and community service through its role and impact in promoting democratic values within society and on this

The research hypothesis is that the university is one of the institutions of the political system that can be used to promote democratic values to serve society. The research will discuss through several axes, the first axis: what is the university environment, while the second axis is the university's role in serving the society the third axis: the role of the university professor in promoting democratic values, while the fourth axis is the university environment and democratic values as well as the introduction and conclusion.
\end{abstract}




\section{المخلص}

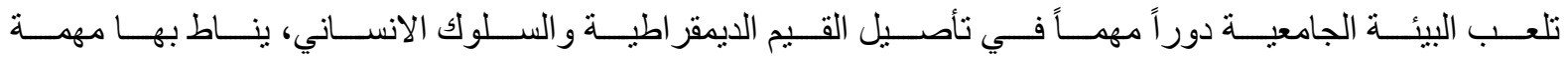
صياغة الثباب فكر ا، وفعلاً ووجداناً.

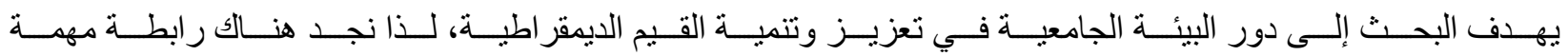

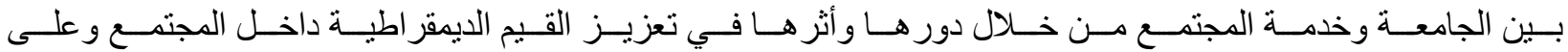
هذا الأساس هناك تساؤ لات:

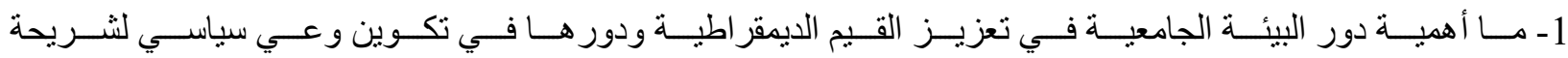
الطلبة.

2- ما هي القيم الديمقر اطية التي يمكن تعزيز ها داخل المجتمع من خلال المؤسسة الجامعية.

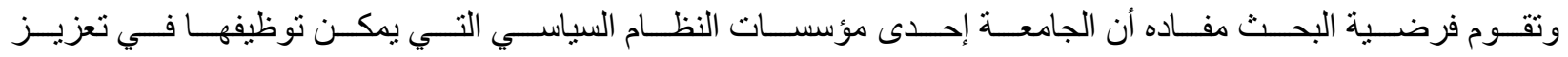

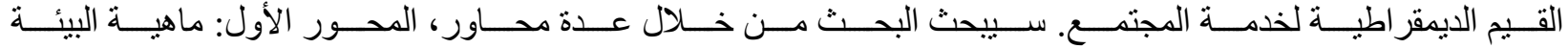

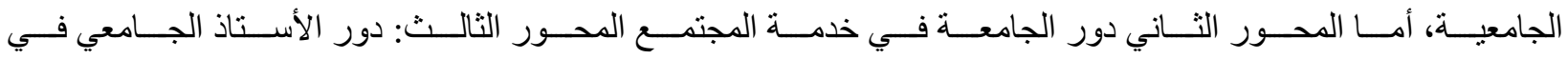

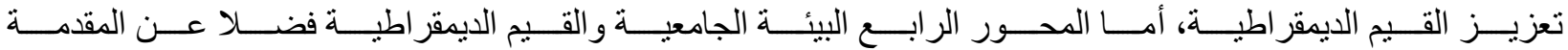
و الخاتمة.

الكلمات المفتاحية : (الجامعات، الأستاذ، القيم الديمقر اطية، المجتمع، الوطن) 


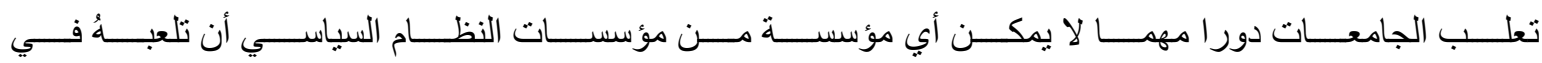

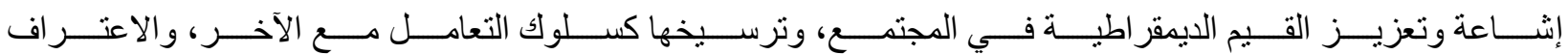

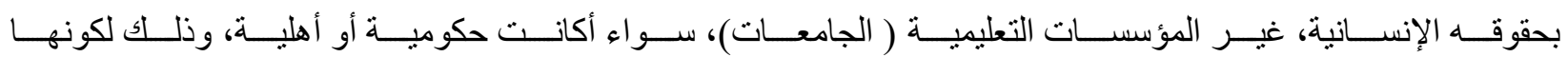
تضطلع بهمة أخلاقية وتربوية في الوقت نفسه.

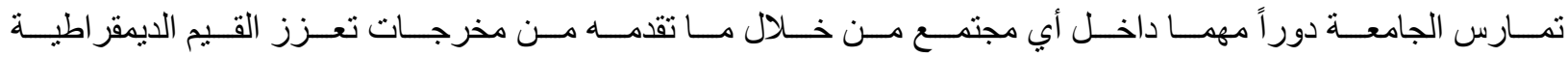

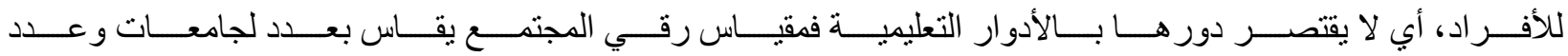
الحاصلين على الثهادات الأولية والعليا وبالنتيجة يشكل المعيار الجمعي الثقافي للمجتمع.

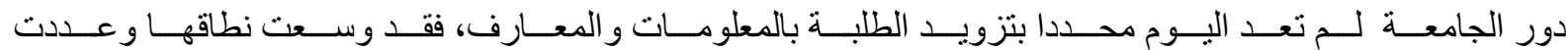

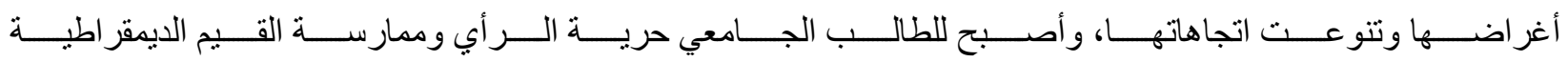

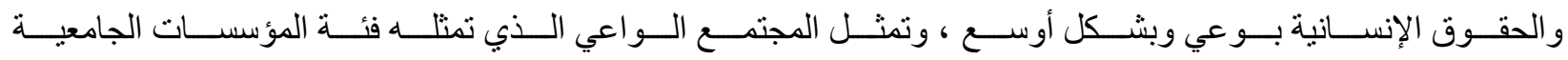
الخاصة و المجتمعية عامة.

\section{أهمية البحث:}

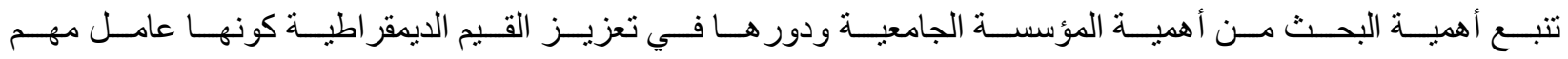

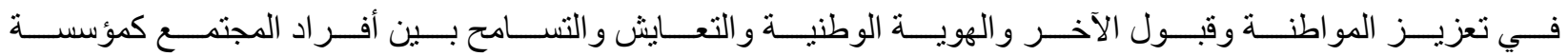

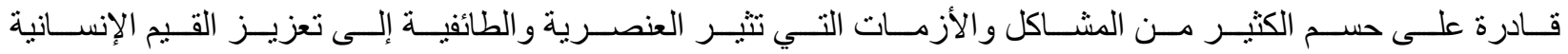
بين المجتمع.

\section{إشكالية البحث:}

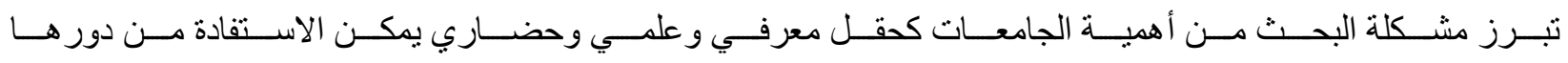

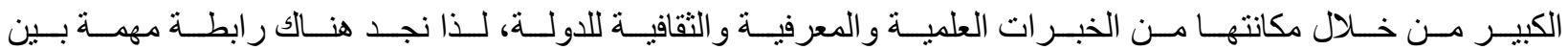

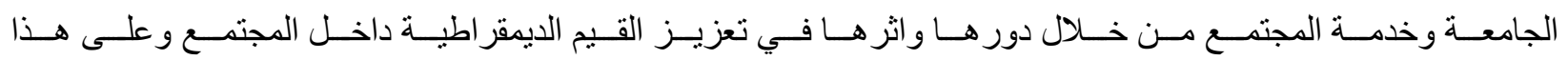

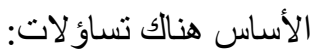




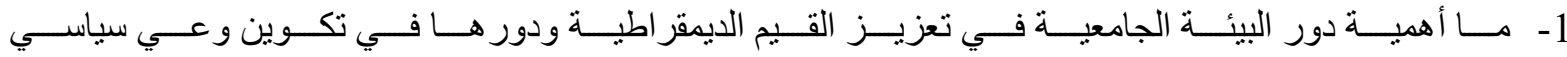

$$
\text { لشريحة الطلبة . }
$$

2- ماهي القيم الديمقر اطية التي يمكن تعزيز ها داخل المجتمع من خلال المؤسسة الجامعية.

\section{فرضية البحث :}

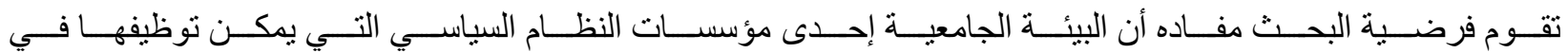
تعزيز القيم الديمقراطية لخدمة المجنمع.

من أجل إثبات فرضية الدراسة والوصول إلى النتائج اعتمدت الدر اسة على منهج التحليل الوصفي .

\section{هيكلية البحث}

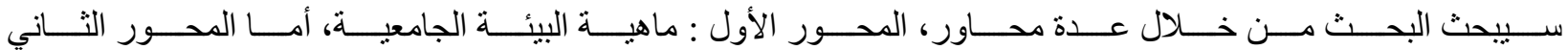

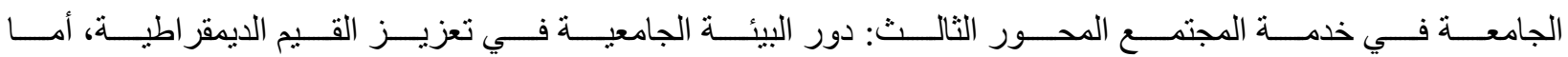
المحور الر ابع الجامعة والقيم الديمقر اطية فضلا عن المقدمة والخاتمة.

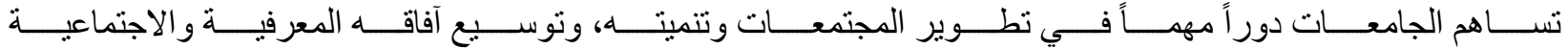

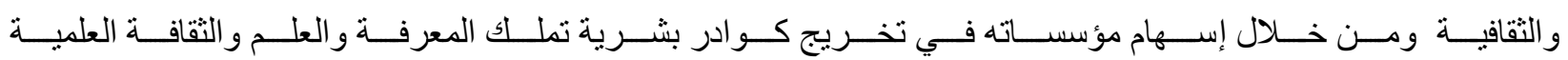

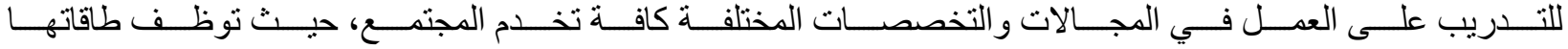

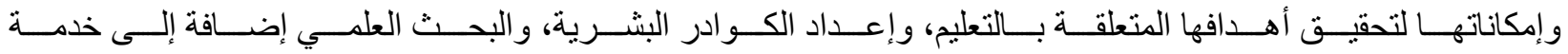

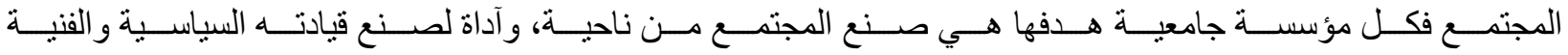
و الإدارية من ناحية أخرى.5[

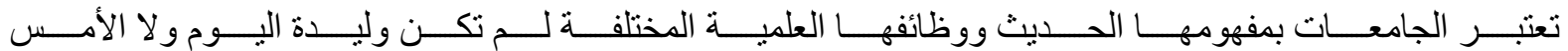

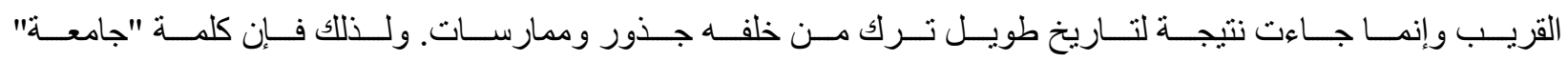




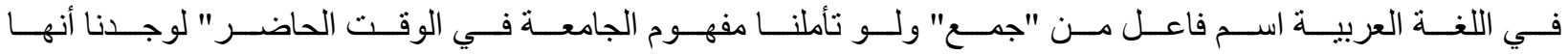

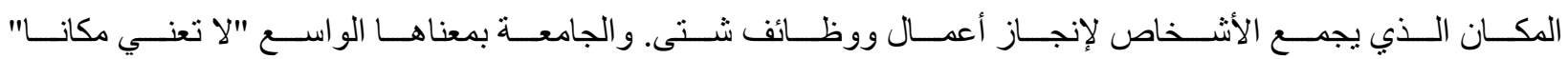

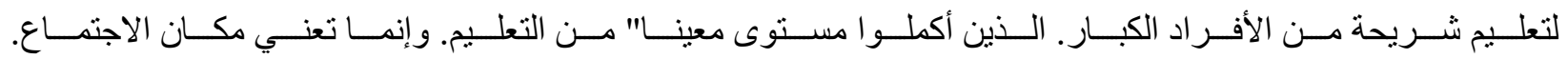
وتعني آداء الثيء جماعيا" كما في القول الصلاة جامعة. [8]

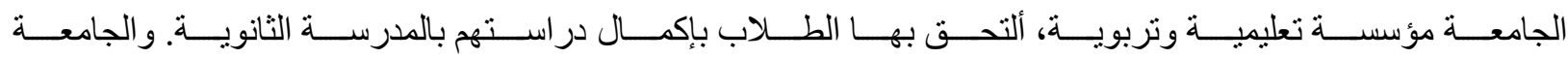

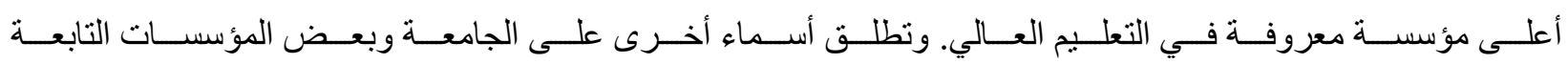
لها مثل: الكلية، المعهد، الأكاديمية، مجمع الكليات التقنية، المدرسة العليا.

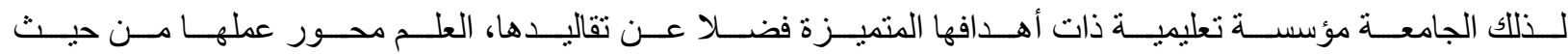

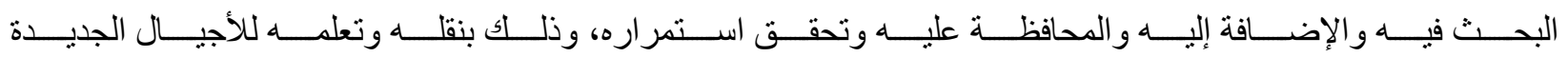

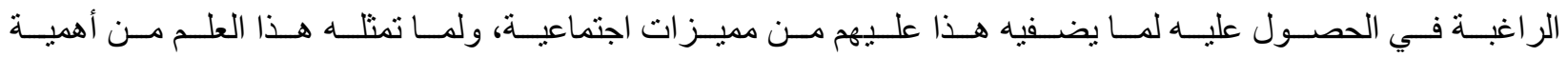

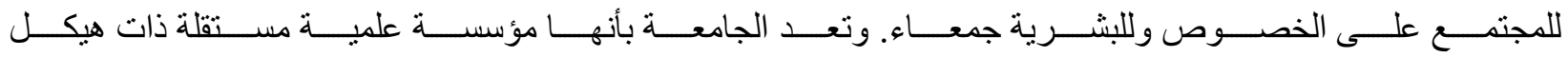

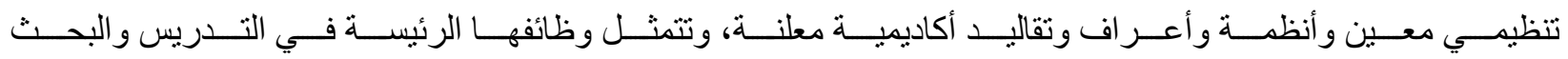

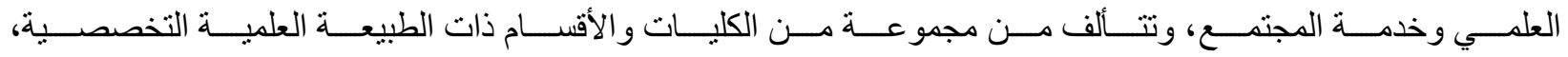

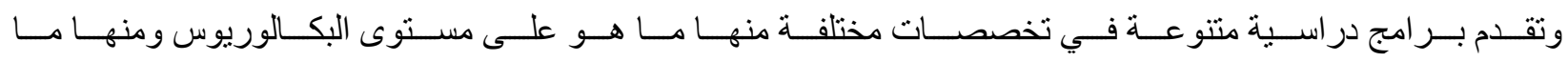
هو على مستوى الدراسات العليا تمنح بموجبها درجات علمية للطلاب.(نفسه)

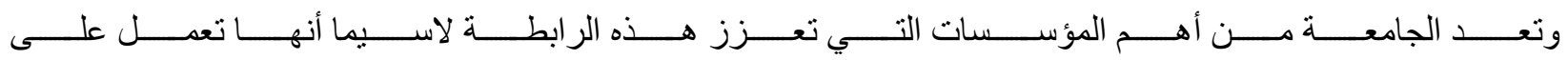

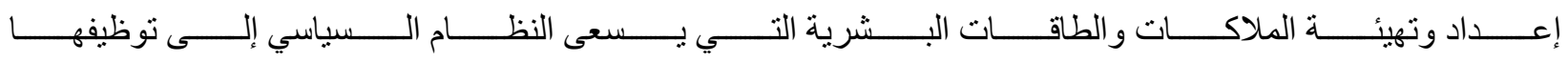

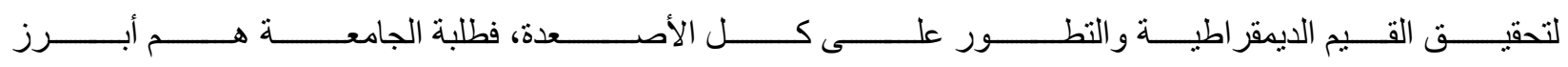
و أهــــم تلــــك الملاكـــات.

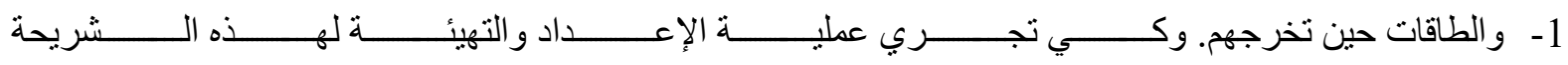

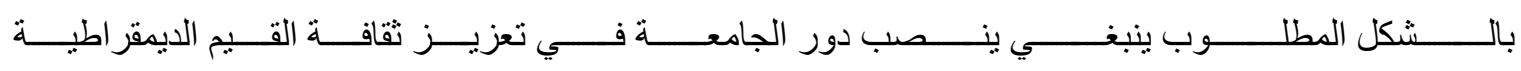

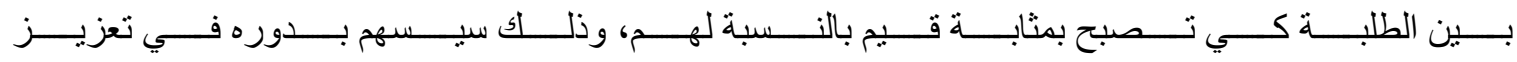

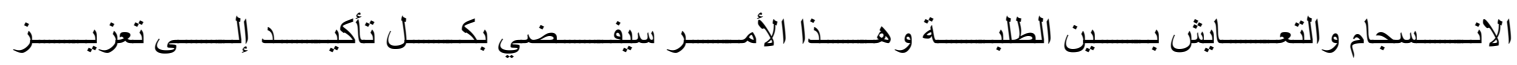




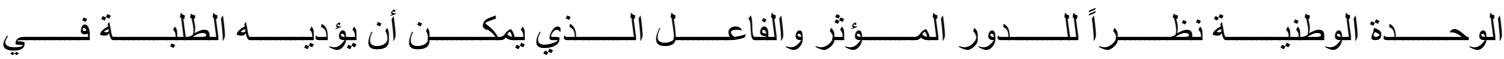

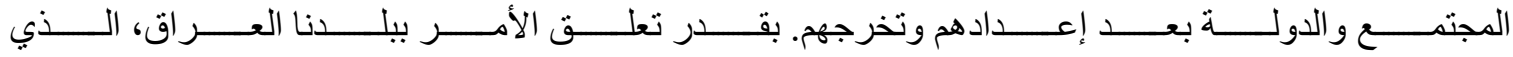

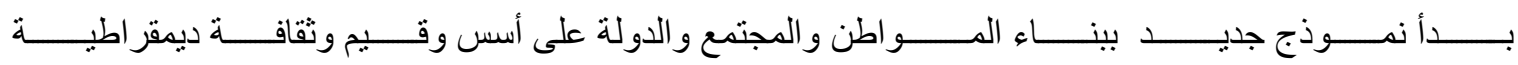

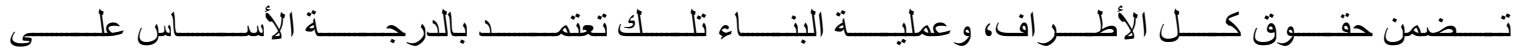

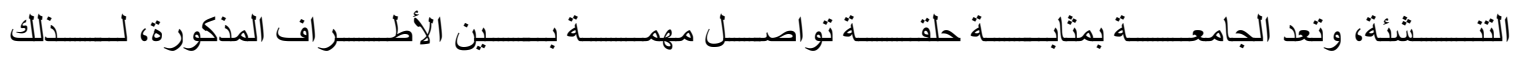

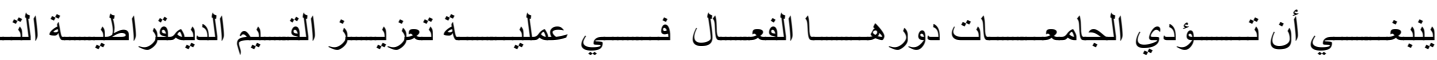

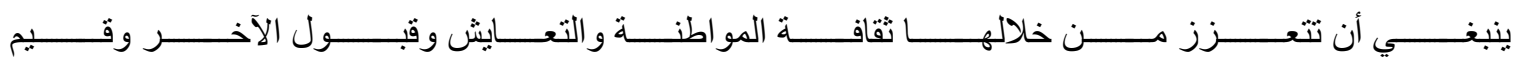
التـسامح. [1]

\section{المحور الثاني: الجامعة ودور ها في خدمة المجتمع}

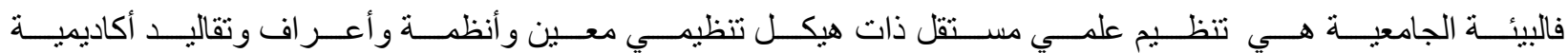

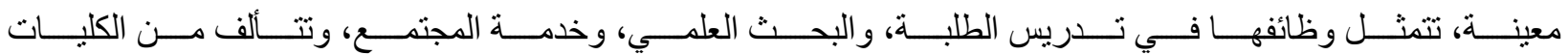

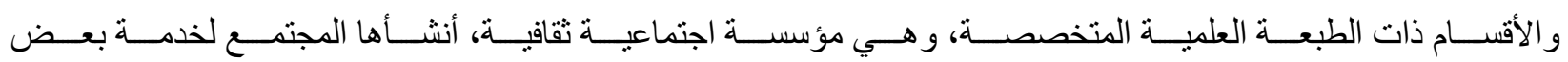

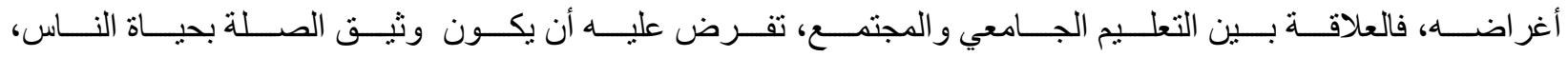

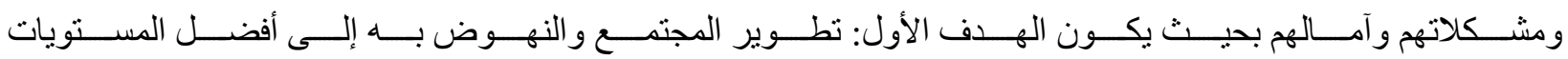

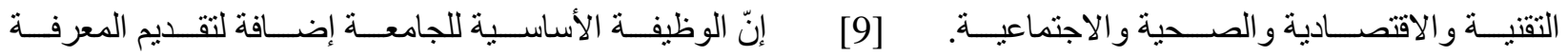
تتمثل بالاستجابة للاحتياجات الفاعلة و الأساسية لتنمية وتطوير المجتمع التي تشمل ما يلي:

$$
\begin{aligned}
& \text { 1- التعليم الجامعي للارتقاء بالمجتمع علمياً وفكريا وثقافياً. } \\
& \text { 2- توفير الإمكانات العلمية و العملية لحل مشكلات و أزمات المجتمع وتمدنه. } \\
& \text { 3- الخدمة العامة للارتقاء بالمجتمع بكل الجوانب الحياة العامة. }
\end{aligned}
$$

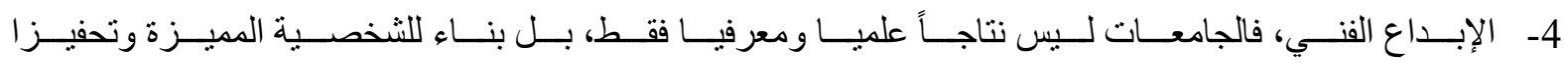

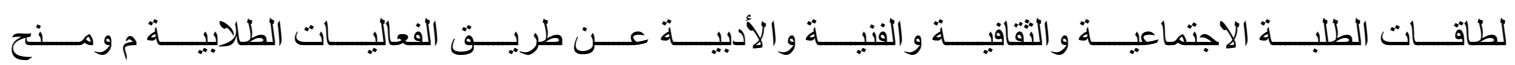
الجوائز التنافسية. 


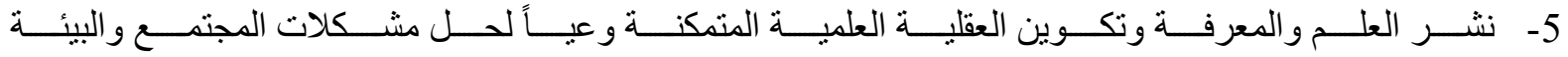
المحيطة، ومعرفة الأساليب الفنية المستخدمة، وتتبعها لركب التقدم العلمي و التكنولوجي.

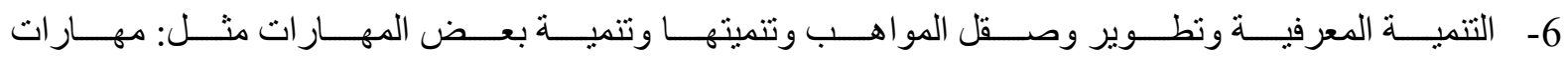
القيادة والإتصال و غير ها وارتفاع مستوى الإبداع و التجدد الذي تتطلبه الأعمال و المهن. 7- دور الجامعة في تعزيز ثقافة حقوق الإنسان وبناء الدولة.

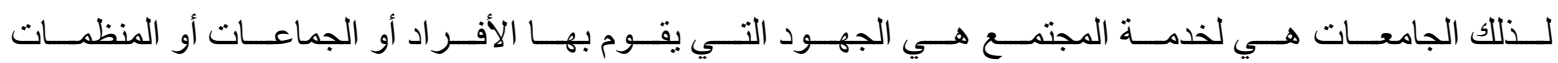

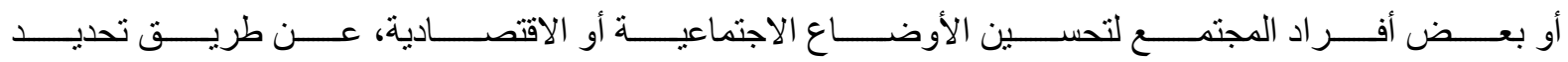
الاحتياج ـــــات المجتمعيـــــة و الاجتماعيــــــة للأفــــر اد و الجماعــــات و المنظمـــــات و المؤسســــــات، وتصــــــميم

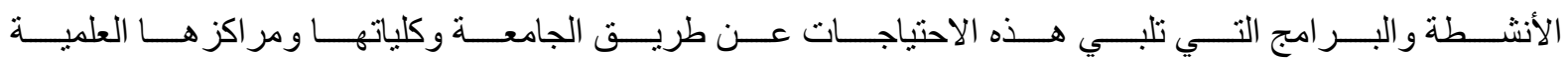

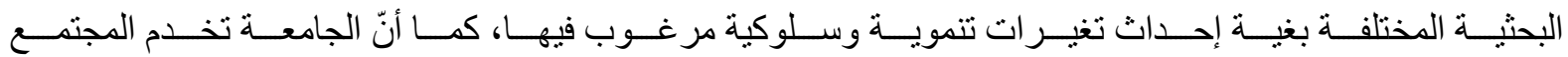

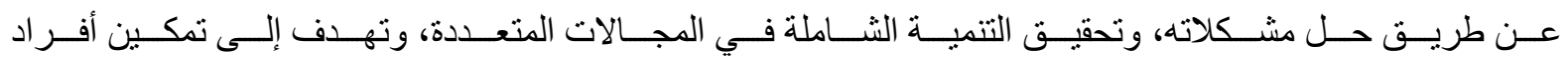

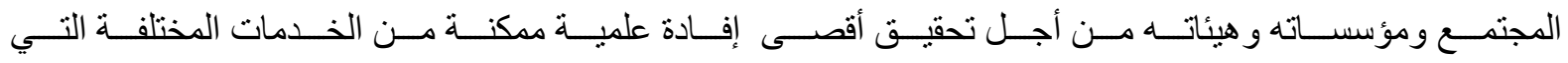
تقدمه الجامعات بعدة وسائل و أساليب متتو عة تتناسب مع ظروف المستفيد وحاجاته الفعلية.

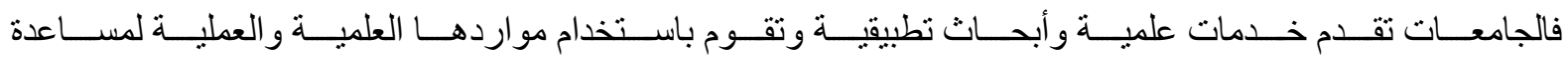
احتياجــات الثــباب غيــر الجــامعي و الكبــار و اهتمامــاتهم بغــض النظــر عــن العـــر أو الجــس أو الخبــر ات

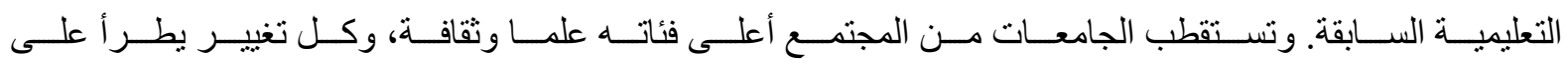
المجتمــع يــنعكس علــى الجامعــات، وكــل تطــور يصــيب الجامعـات يصــاحبه تغييــر وتجــد فــي المجتمــع الذي نعيش فيه، فالجامعة لا تنفصل عن المجتمع، و علاقتها بالمجتمع كعلاقة الجزء بالكل. [8] المحور الثالث: دور البيئة الجامعية في تعزيز القيم الديمقراطية:

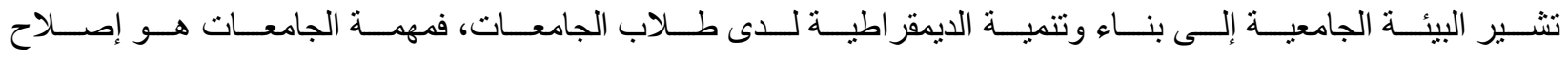

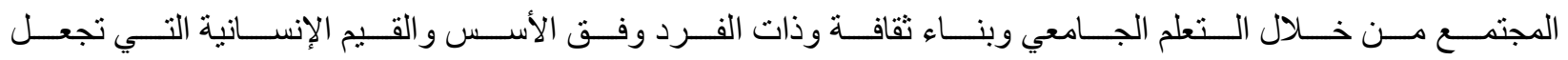
الإنســان عضــواً فــالاً إيجابيـاً فــي الحيـاة العامــة و الخاصــة. لـــللك سـنتطرق إلـى أهيــة عـدة أسـس التـي تعـزز 


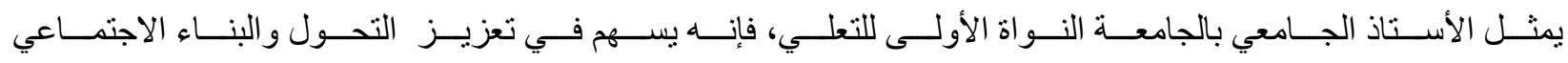

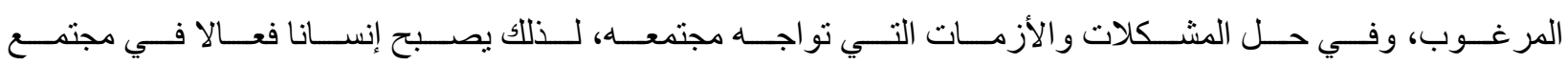

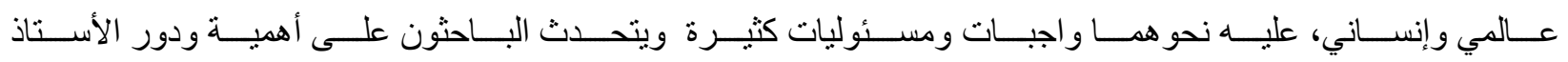

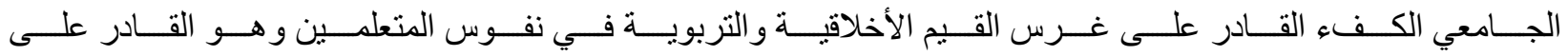

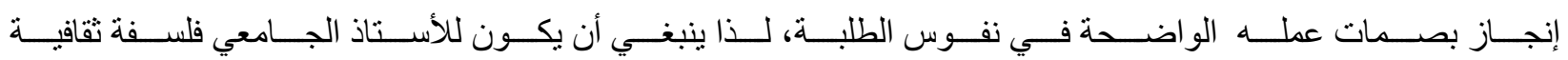

$$
\text { وتربوية و اضحة عن المعرفة و التدريس والتعلم. }
$$

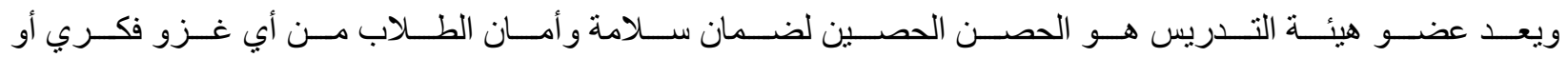

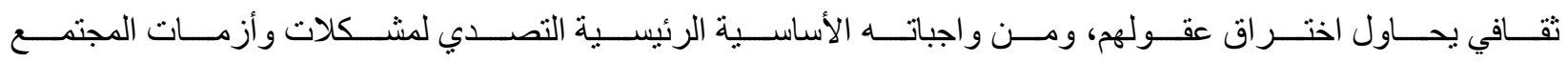

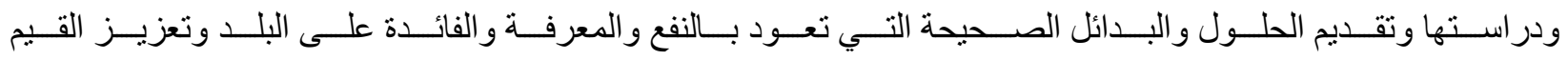
الديمقر اطية في المجتمع. [4]

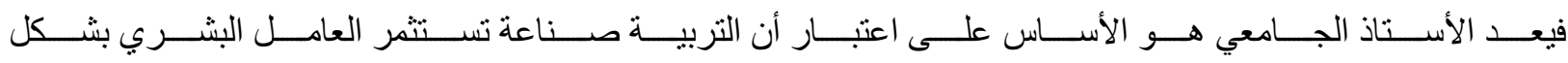

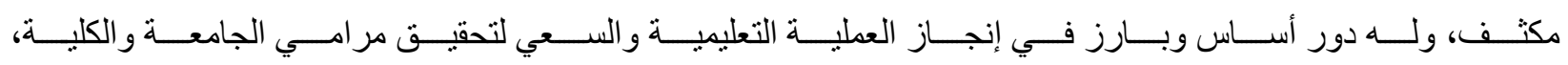

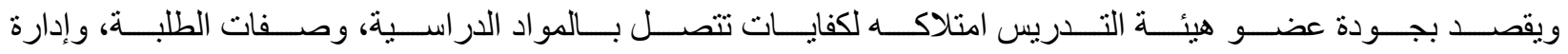

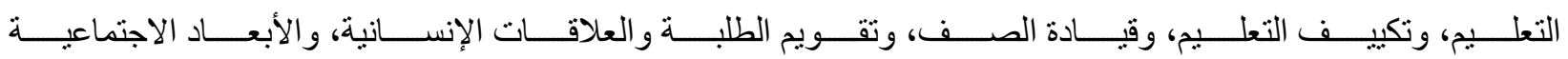
و الثقافية لمهنة التعليم، وكفايات مهنية عامة، وبناء على هذا الأساس، يوجد مؤشرات متعددة وهي:

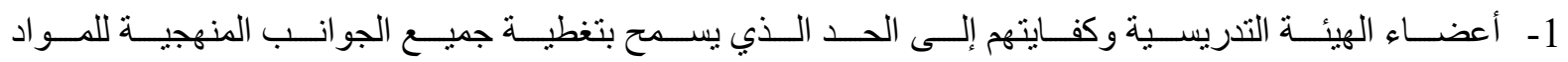

$$
\text { التعليمية وبحسب الاختصاص. }
$$

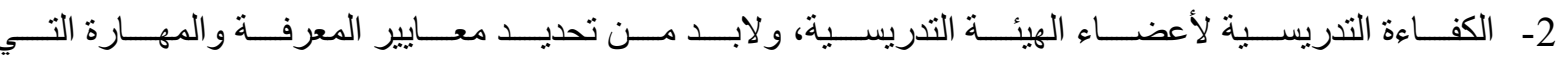
يتوقع أعضاء التدريس امتلاكهم لها ومدى نمو هم المهني المستمر في مجال الاختصاص. 3- المساهمة في تتمية وخدمة المجتمع المحيط بهم. 4- مستوى الأنشطة التدريبية والتأهيل المؤسساتي الأكاديمي لأعضاء الهيئة التدريسية. 


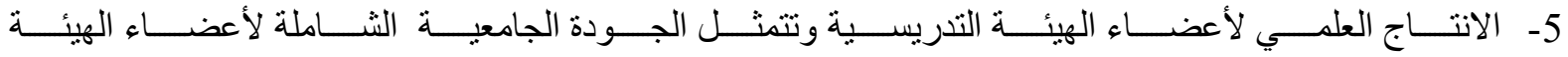

$$
\text { التدريسية في اختيار هم الموضو عات العلمية البحثية التي تتسم بالتجدد والابداعية. }
$$

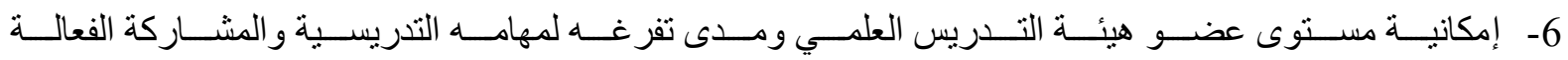

$$
\text { في الجمعيات العلمية و المهنية وغير ها. [2] }
$$

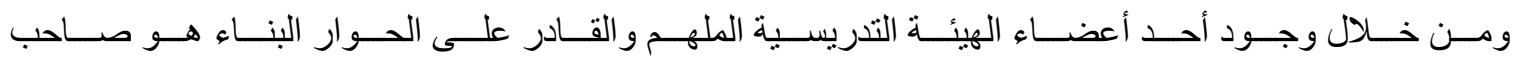

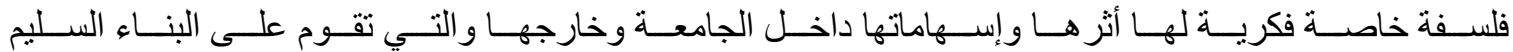

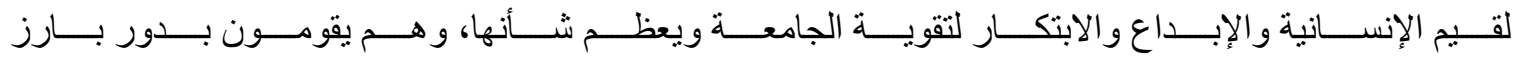

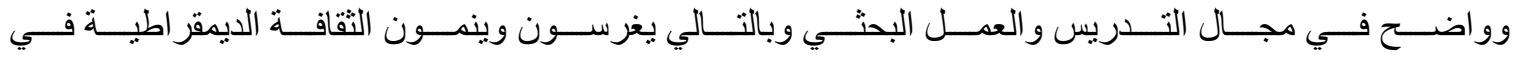
طلابهم .

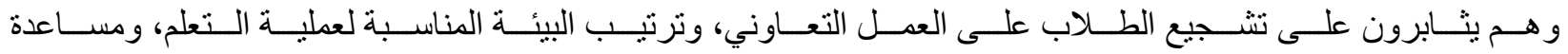

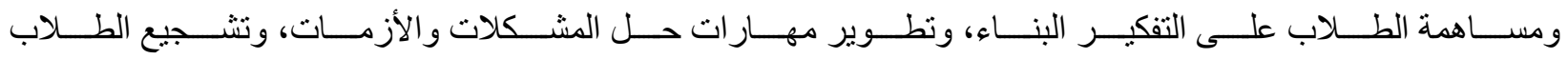
على استخدام التكنولوجيا الحديثة، ومساعدتهم في التعبير عن آر ائهم و أفكار هم . وفي غرس القيم و الثقافة القيمية لاى الطلاب، يقوم الأستاذ الجامعي بالأمور التالية: 1- تطوير ومساعدة الطلاب في اكتشاف قيم البناء المرتبطة بثقافة التغيير و التجدد في مجتمعنا.

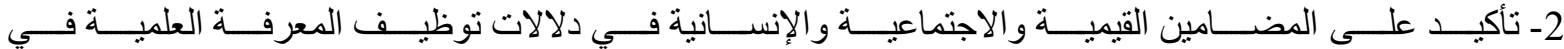
المجنمع. 3- تعريف وتعليم الطلاب بطبيعة العلم وثقافة العلم و علاقتها بالمجتمع. 4- تمكين الطلاب على فهم وتقدير كيفية الارتباط بين قيم العقيدة وقيم ثقافة التغيير.

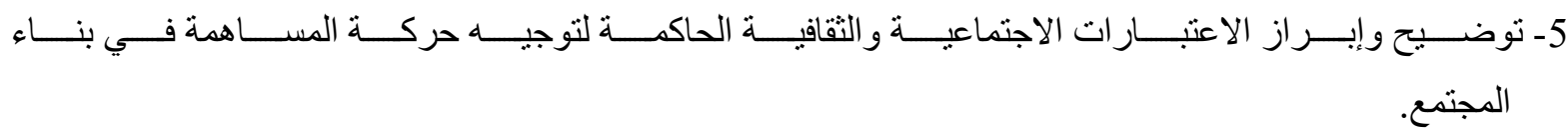

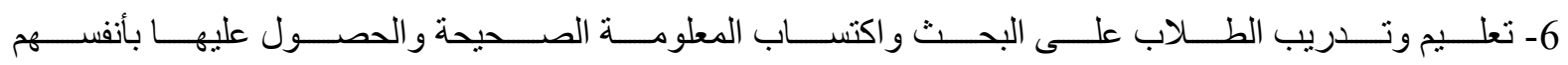
و إتقان التعامل مع التقنيات الحديثة . 7- تطوير مهار ات الطلاب في استخدام وتطبيق التكنولوجيات الحديثة . 


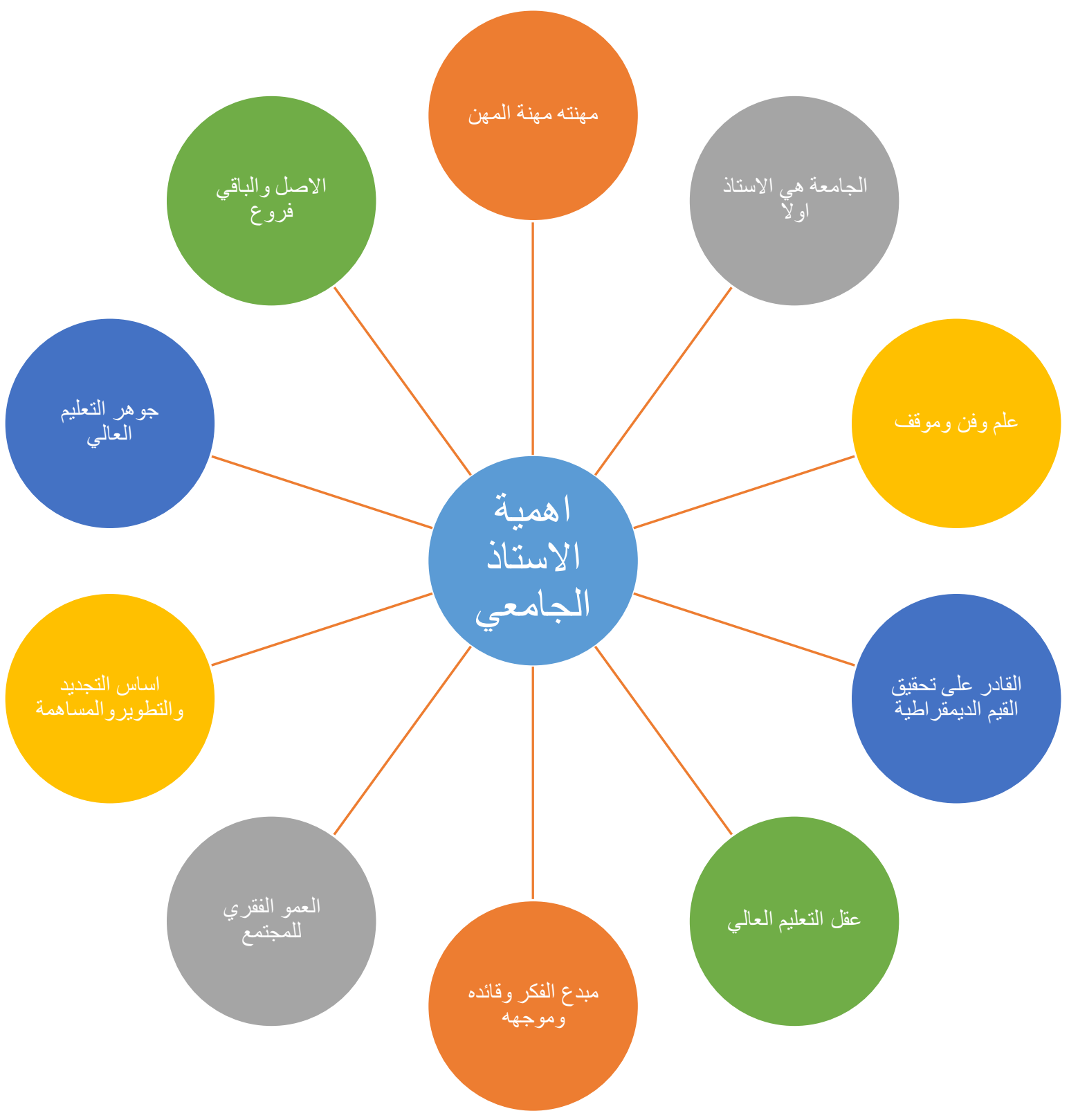

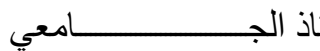

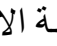

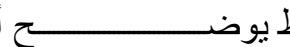

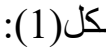




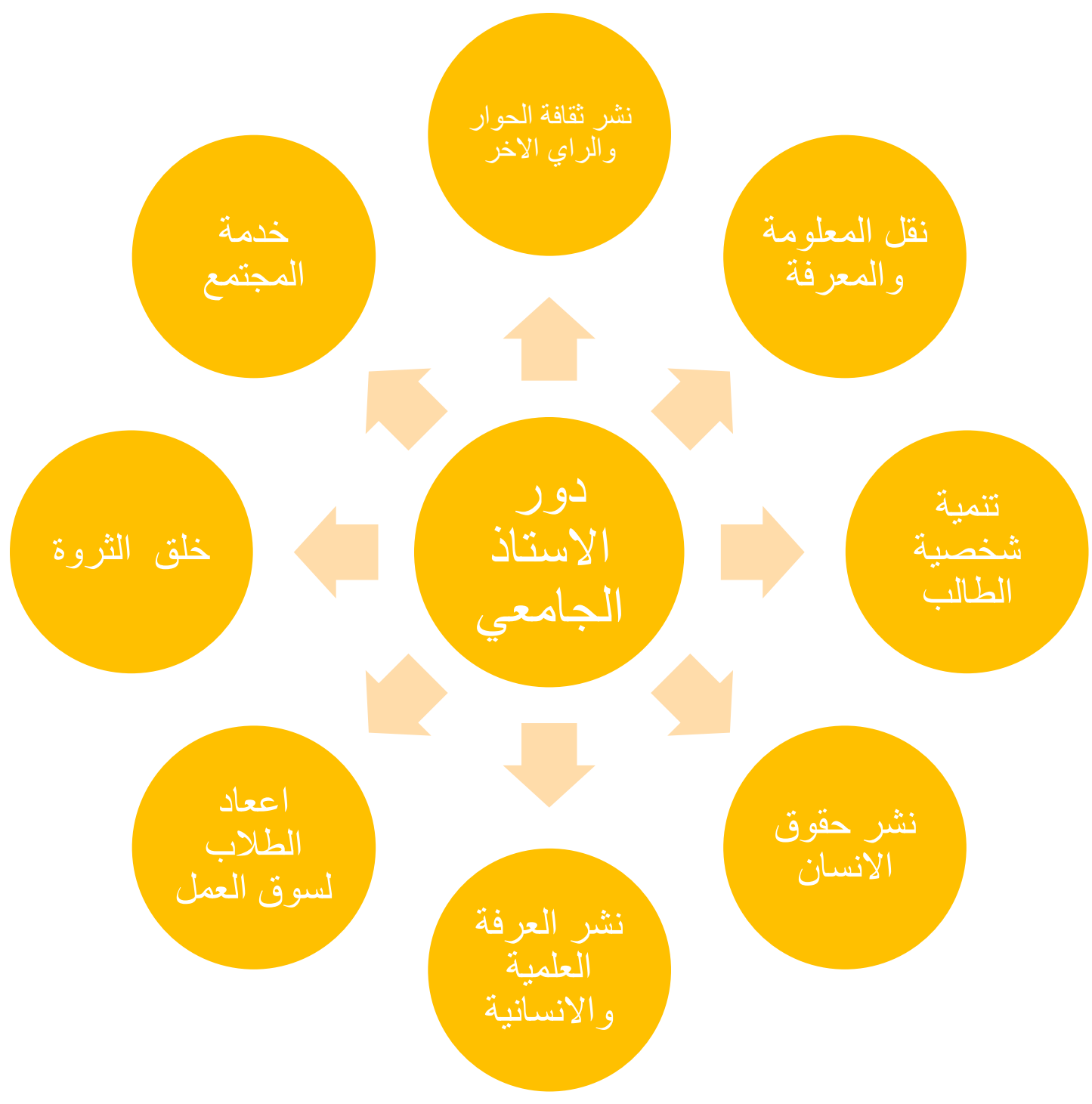

شكل(2): مخطط يوضح دور الأستاذ الجامعي

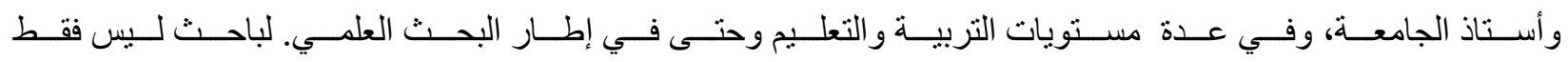

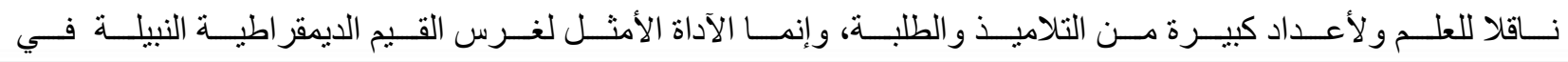




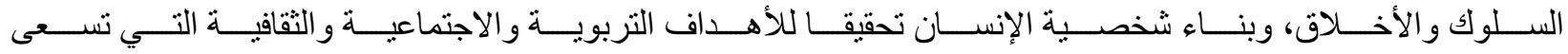

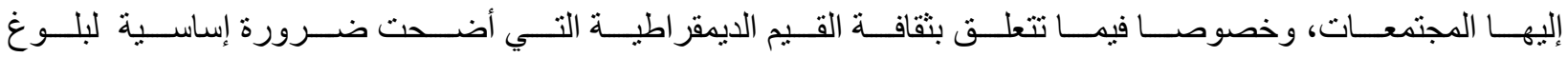

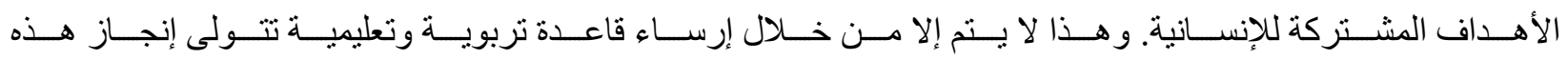

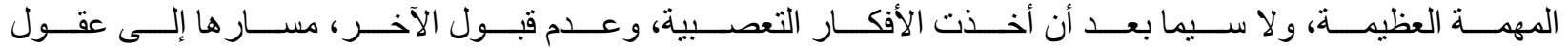

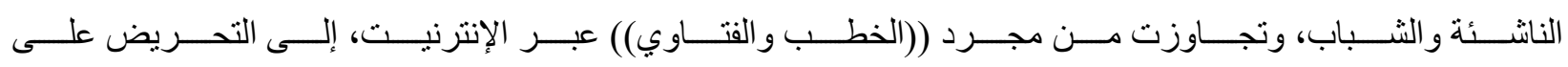

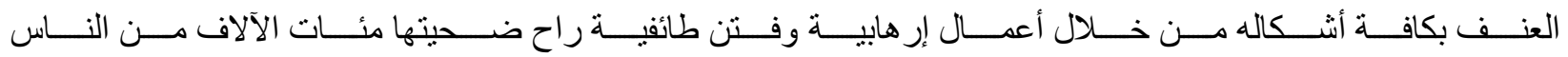

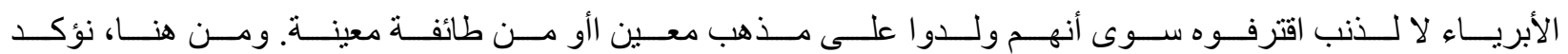

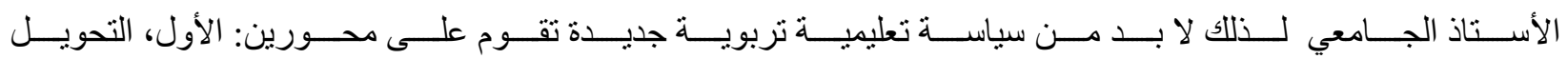

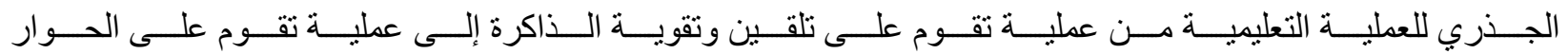

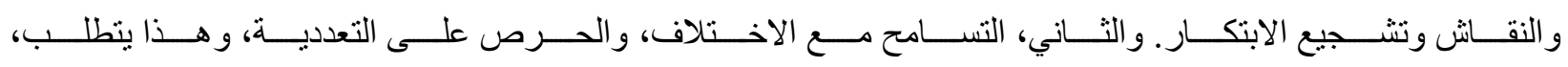
تعــديلات جذريــة فــي المنــاهج إعــادة تــدريب المدرســين علــى مبــادىء الفلســفة التعليميــة الإبــــاعي، فــتح

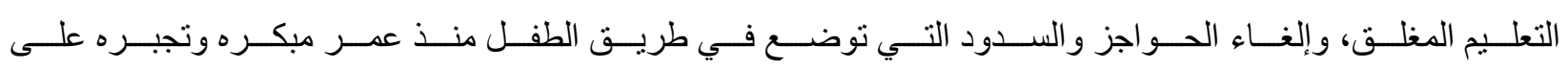

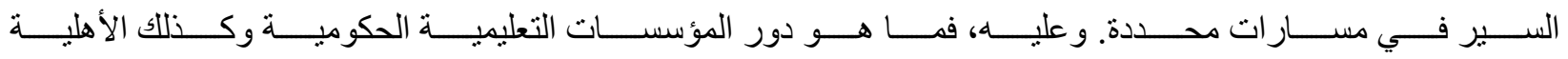

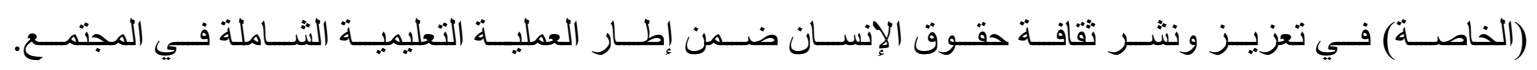

تهنم الجامعات بالأنشطة الطلابيـة اهتمامـا بـارزاً بوصفها عاملا مهمـا في تتميـة القيم الديمقر اطية للمجتمع ـ فترتكز المجتمعات المزدهرة في تطور ها ونمائها على حسن استثمار مواردها الطبيعية، و إمكاناتها البشرية، والاستفادة من جميع الطاقات الإنسانية، الأمر الذي يدعونا إلى تعرفها وتحديدها في الجسم والعقل والنفس. والطريق إلى ذلك هو إتاحة الفرصـة لها للظهور كي يمكن تعديلها وتهذيبها وتتميتها ولم يقتصر دور التعلم والتربية الحديثة على القاعـات الدراسية في تزويد الطالب بالثقافة العلميـة العامـة الأساسية، وتتمية القيم الديمقر اطية و الاتجاهات و الميول و المهارات و أسـاليب التفكير المرغوب فيها فحسب، بل تغيرت وجهتها إلى الاهتمـام بالإنسـان من جميع جو انبه على اعتبار أنهه شخصية متكاملة، و أنها عضو مهما وفعّالاً في المجتمع و عليه أصبح الطالب الجامعي في وسـائل التعليم الحديثة هو المحور الذي تدور حولـه العملية التعليميـة والتربويـة ، وأصبح الهدف الأسمى 
و الأساسي من التعليم هو تتميـة شخصيته وقدر اته الفكريـة، وإحداث التغيرات الإيجابيـة فيها، حتى يتمكن من معايثـة متطلبات الحياة العصرية المليئة بالمتغير ات العديدة.

إن إحداث هذه التغيير ات و التجديد يتطلب تغيير اً وتمكيناً في مسـار الحياة العلميـة الدراسية، التي ينبغي أن تتضمن الممارسـات العملية لكافة ظروف الحياة في المجتمع، ويمكن أن يتأتى ذلك من خلال ممارسة العديد من ألوان الأنشطة الطلابية. ذلك أن الحياة الجامعيـة ينبغي أن تكون حياة متكاملة، فالجامعة ليست محاضرات ومعارف ودروس علميـة فحسب، و إنما يجب أن تستهدف التكوين المتكامل للطلاب، والعناية بنمو شخصياتهم، و هذا يقتي قيام أنواع مختلفة من الأنشطة. هي تعني الأنشطة ذات الطابع الأكاديمي و غبر الأكاديمي وتوظيف وتطوير قدرات الطلاب ومو اهبهم ورعايـة الطلاب ومعالجـة مشكلاتهم وأزماتهم الاجتماعية وتأهيلهم نفسياً وثقافياً ورياضياً. تعد الأنشطة الطلابية التي تجعل الجامعة مجتمعاً متكاملاً يتدرب فيه الطلاب على الحياة المجتمعيـة، يكتسبو ا من خلالها خبرات وتجارب المجتمع، وتبث فيهم روح الجماعة وتدربهم على القيادة و التشاور و التعاون، والتفاهم المتبادل، كما تدعم شخصياتهم بمـا يلاقونه من تحديات وما يقابلهم من مشكلات، وما يتحملونه من مسؤوليات. [6] و نعد الأنشطة الطلابية هي المجال الحيوي و الطبيعي الذي يكتسب من خلاله الطالب الجامعي الخبرات المتتوعة و الحديثة ، حيث تتضمن هذه الأنشطة أمور اً متعددة تتعلق بالجو انب: النفسية والبدنيـة والحركية و العقلية، والاجنماعية، و الثقافية ، والفنية وغير ذلك. فلا يقتصر دور المؤسسـة التعليميـة ـ الجامعة ـ علي مواد تخصصية، و إنما تربيـة متكاملة دينياً وخلقياً، و إتاحسة الفرصـة للطلبـة لممارسـة الديمقر اطيـة و الحـو ار البنـاء و التعـايش و القيـام بالنشـاط الفكري و الثقافي و الاجتمـاعي و الرياضـي، وكذلك تنميـة المفـاهيم الإنسـانية والعلميـة ، وحب الخير و عدم التعصب الأعمى، وعلى الطالب أن يحيا حياة در اسية جامعية كاملة، وغرس المفاهيم السليمة و السلوك المثالي لتصقله وتطوره ـ فتعمل الجامعات على تنمية شؤون الطلاب على تهيئة وتفعيل الحياة الجامعية الملائمة للتحصيل العلمي والقيام بالدور العلمي والتربوي مما ينعكس إيجاباً على شخصية الطالب الجامعي و تحصيله الأكاديمي، كمـا تلعب مؤسسـات التي تدير شؤون الطلاب دوراً مهماً وفعالاً في تربية وتنشئة الطلاب على حب الوطن والخير والمودة و التعايش السلمي و السلم الأهلي والتسامح بين المجتمع .

و هناللك عدة و سائل للأنشطة الطلابية لتنمية القيم الديمقر اطية لدى الطلاب الجامعات بما يلي: [7]

$$
\text { 1 - تعزز قيم المو اطنة والانتماء و الهوية . }
$$


2- تعزز نبذ العنف والتمييز بأشكاله.

3- تنمي قيم التعاون بين الطلبة

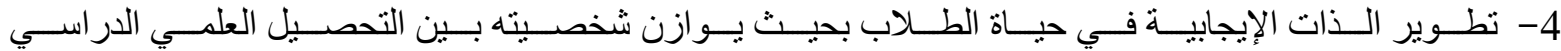
و النشاط الطلابي اللاصفي .

5- تعزز الأنشطة الطلابية العمل الطوعي لاى الطلبة..

6- تعزيز الرعاية العلمية الثقافية والاجتماعية والرياضية.

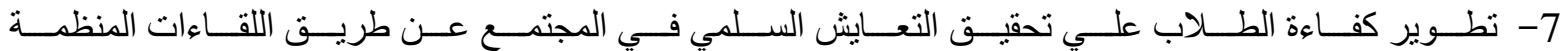

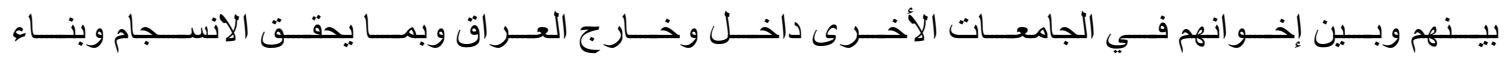

الخبر ات.

8- تثقيف الطلبة على المشاركة الاجتماعية وتنمية العلاقات الأخوية بينهم وبين أساتذتهم.

9- 9 - توفير الراحة و الطمأنينة للطلاب.

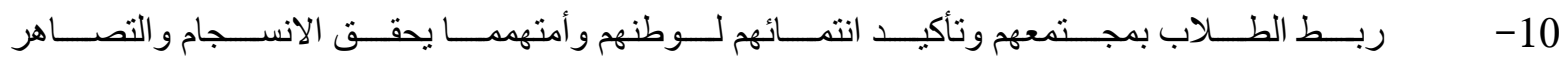

بينهما.

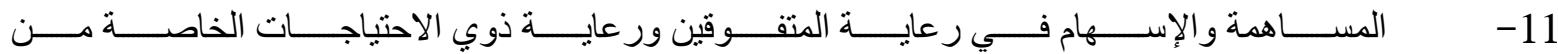

الطلاب .

ثالثاً: المنهاج الاراسي

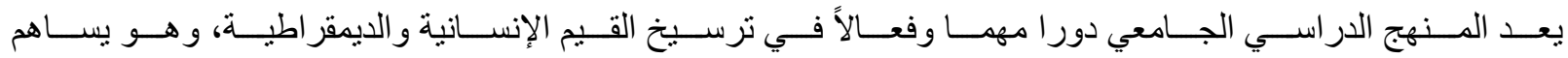

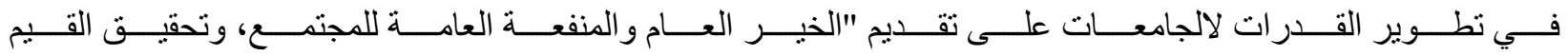

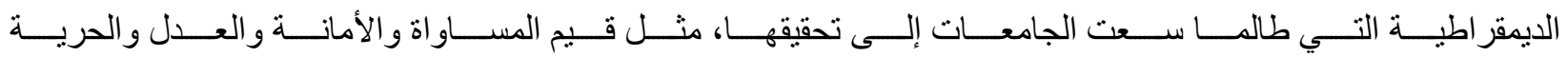

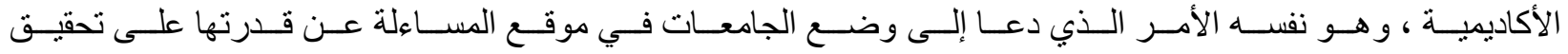

التوازن بين تقديم الخير العام للمجتمع، و المسنوى الأكاديمي، ومتطلبات السوق. 


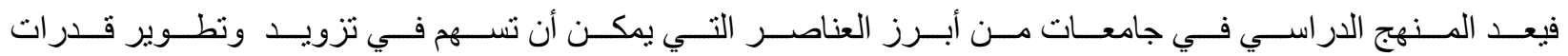

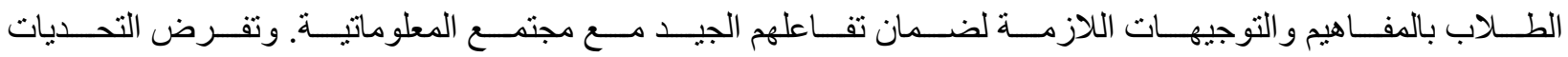

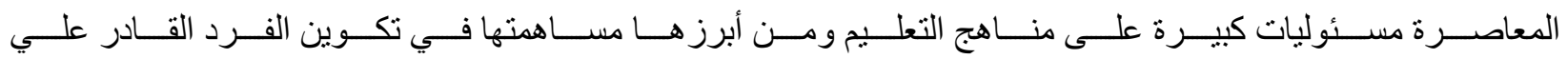

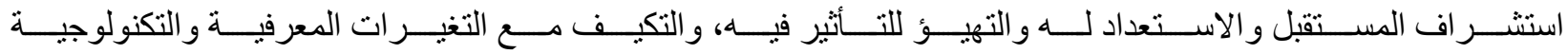
المتسار عة، و التعلم الذاتي، فضلاً عن التمتع بالعقلية الناقدة و المبدعة. [10]

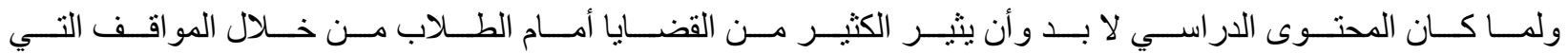

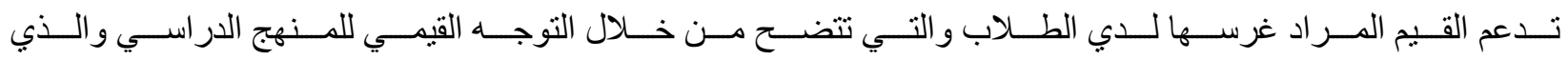

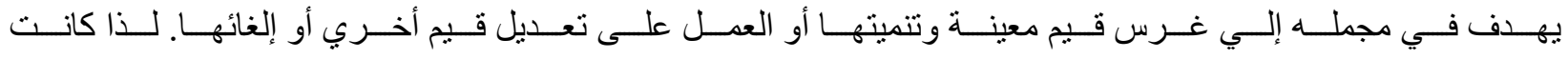

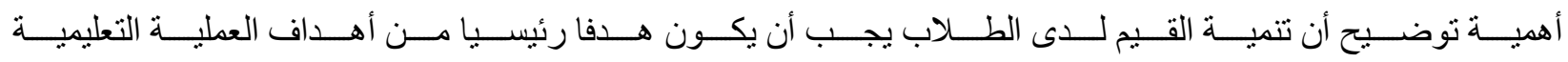
و الذي يمكن الاستعانة به في تخطيط البر امج التربوية داخل المؤسسات التعليمية .

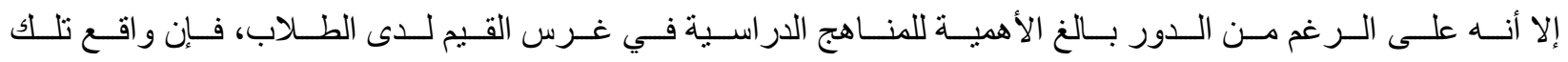
المنــاهج يبـــور كثيــراً مــن المشــكلات التــي تعــوق التنميــة القيميــة للطــلاب داخــل الفصــل الدر اســي ومنهــا: أن

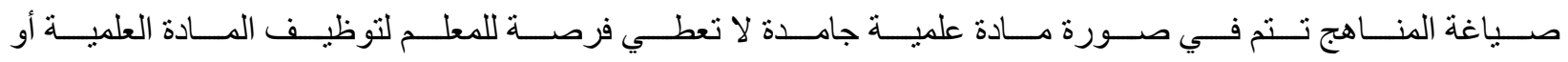

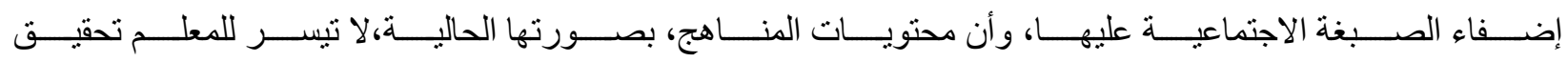

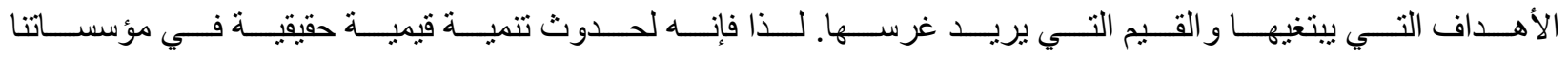

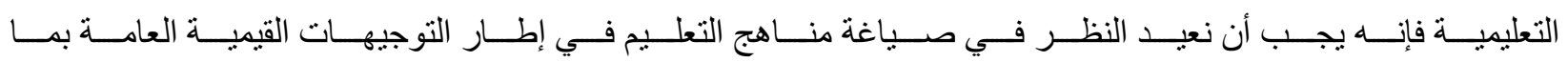

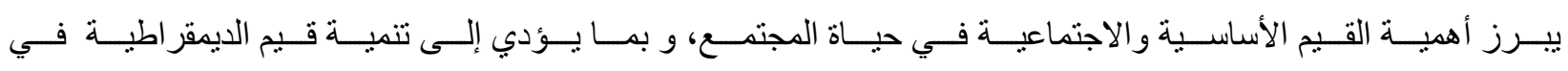
المجتمع.

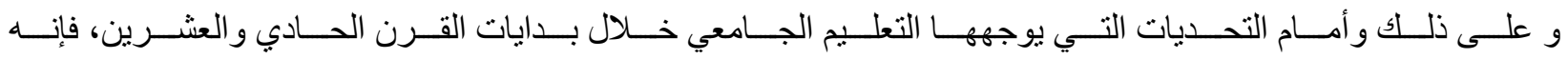

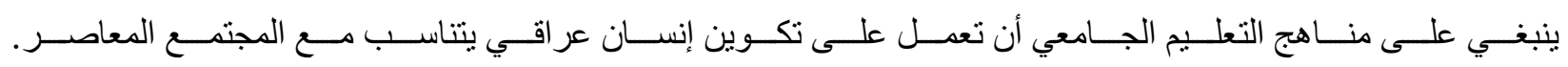
ويتميز بالقدرة على: 1- الفكرة المنطقية الو اقعية و التمسك بالأسلوب العلمي في حل المشكلات و الأزمات. 


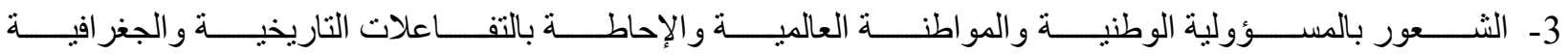

$$
\text { و الوعي بالمشكلات العالمية (تلوث البيئة، الإرهاب، البطالة... ) }
$$

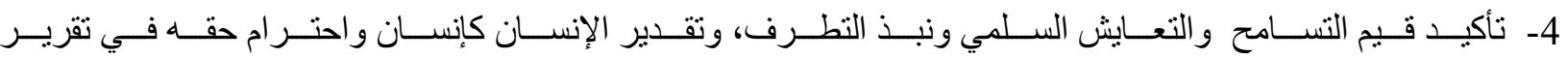

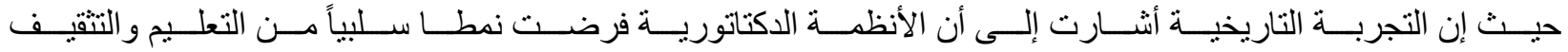

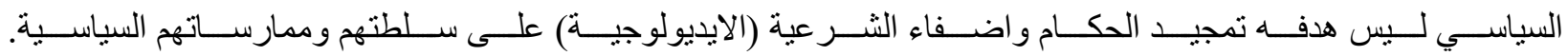

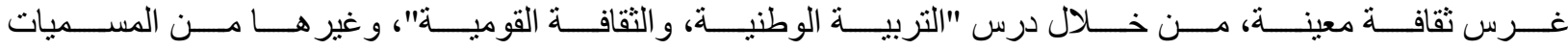

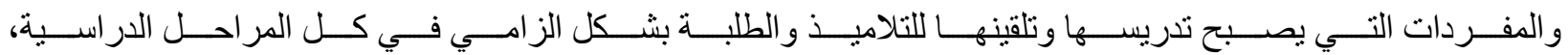

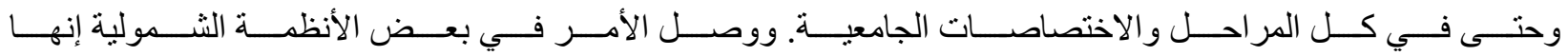

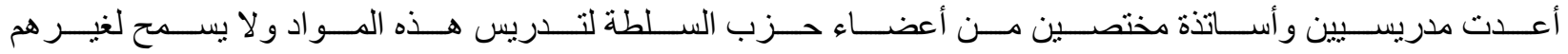

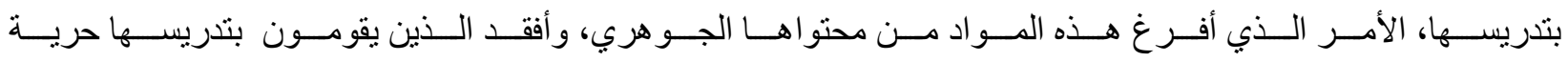

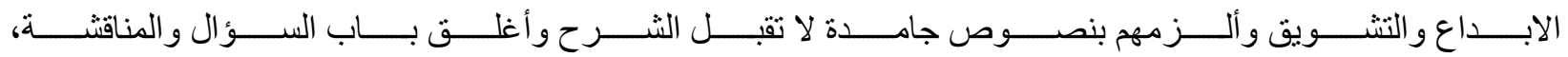
وتثير الإحر اج و الخوف أحيانا. [10]

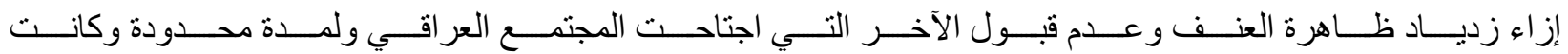

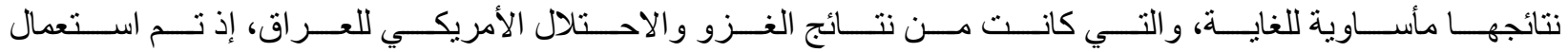

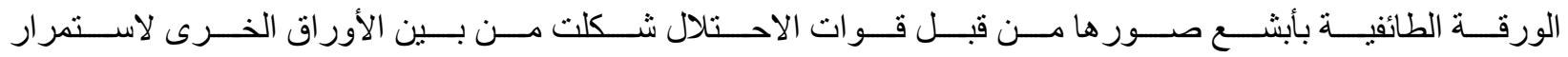

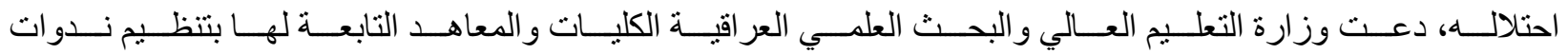




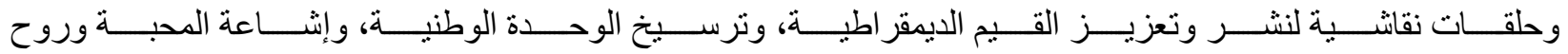

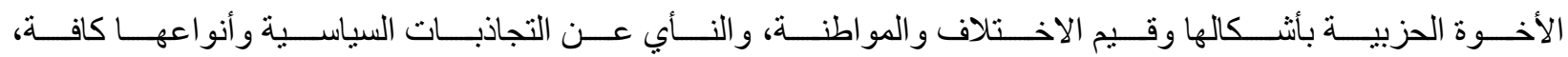

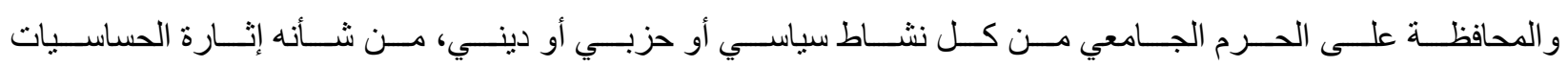
والنعر ات الطائفية.

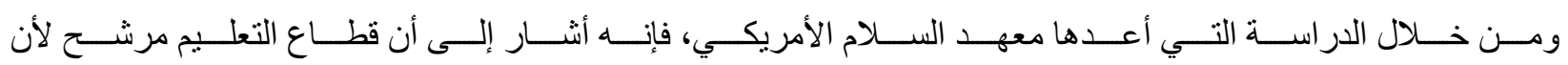

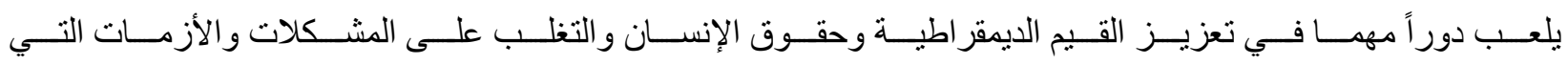

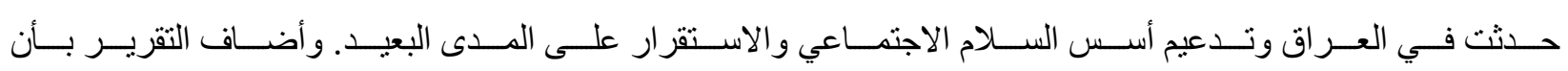

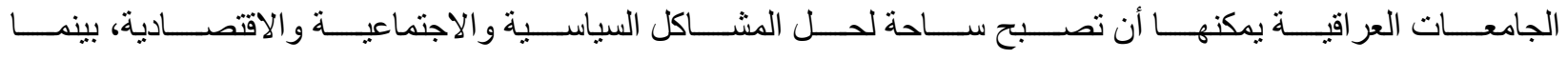

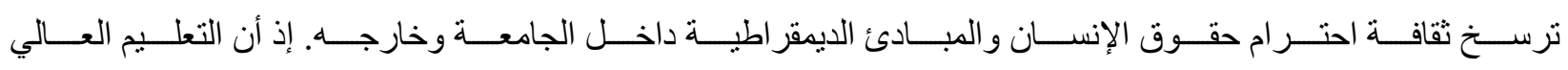

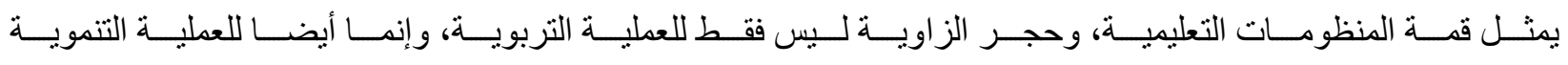

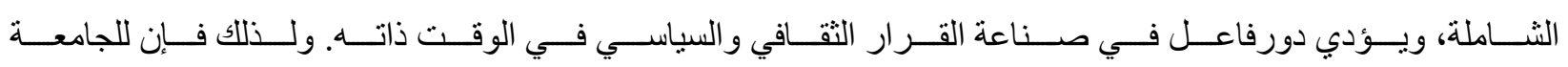

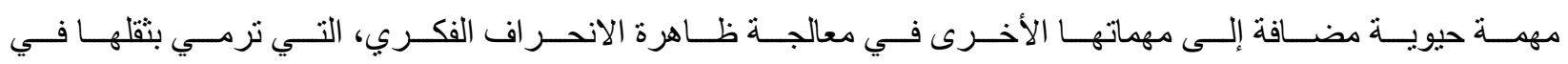

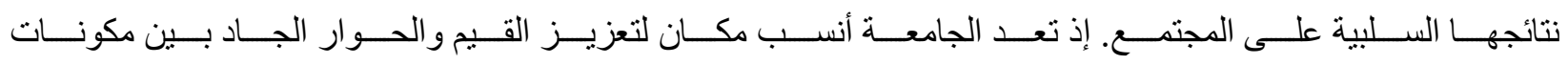

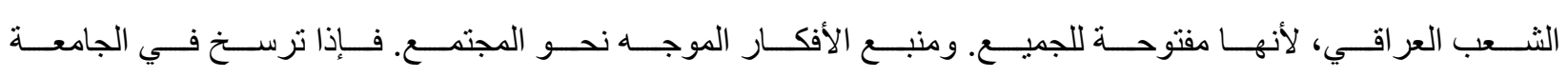

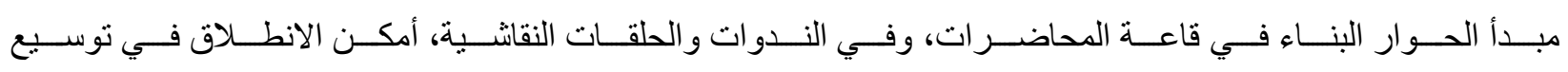
دائرة الحوار وقيم التسامح نحو المجتمع مع توالي الاجيال المتخرجة من الجامعات العر اقية. [3]

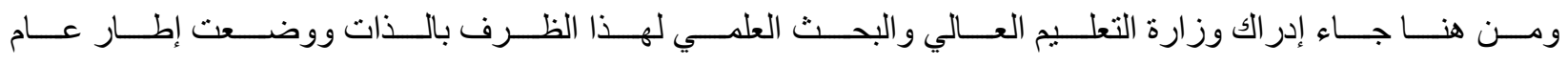

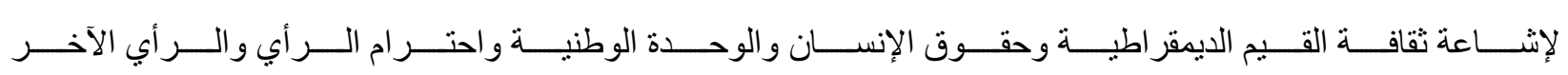

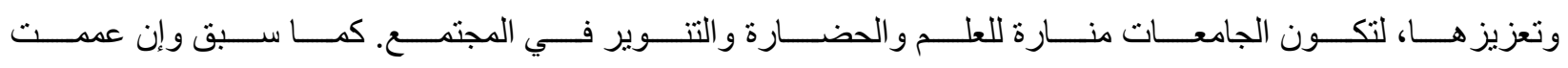

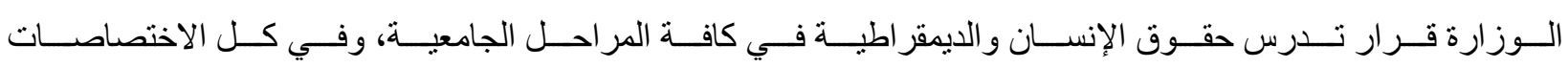

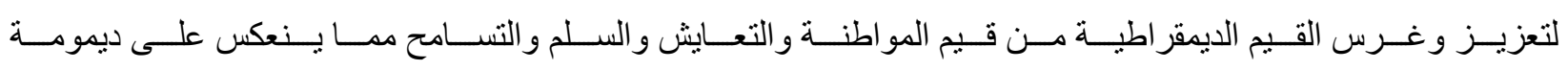
المجتمع نحو الأسس السليمة لبناء دولة قوية . 


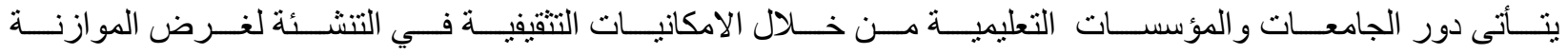

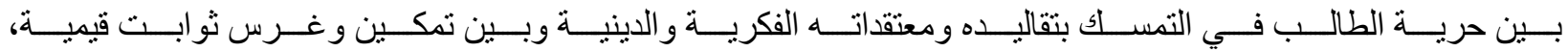

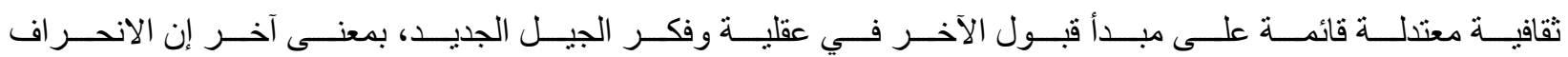

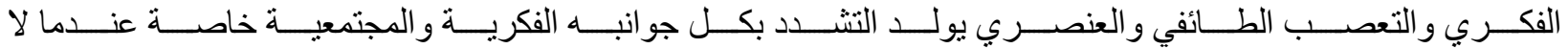

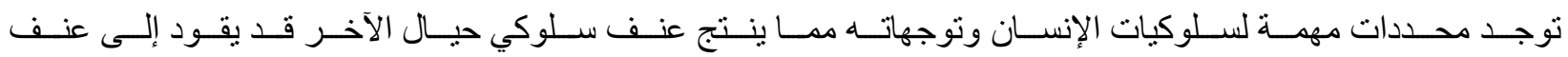
سياسي وفكري.

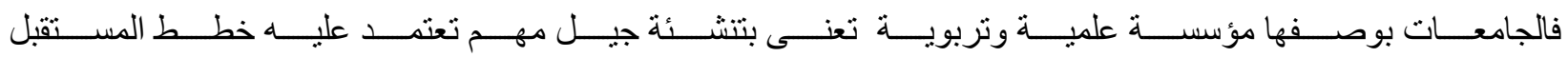

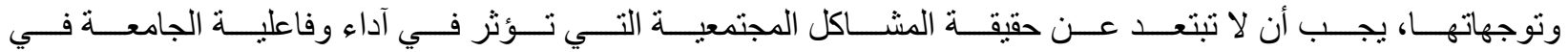

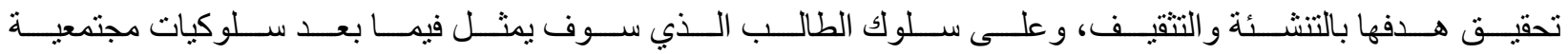

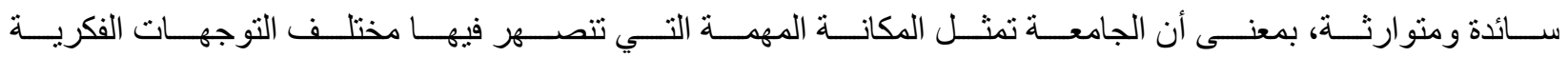

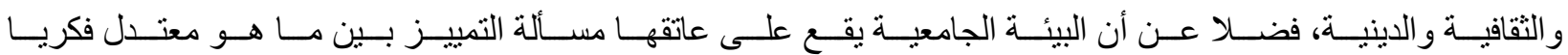
ومقبول وبين ما هو متطرف مرفوض. [3] فتعـــ المنظومــة الجامعيــة التعليميــة التــي انتجــت حالــة مركبــة مـن التعـاطي المجتمعـي ســواء بــين الطلبــة مــن

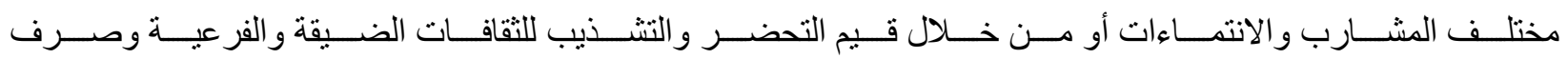

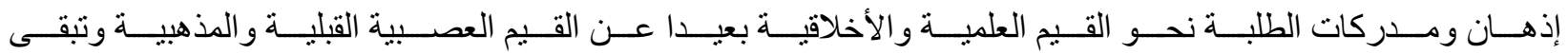

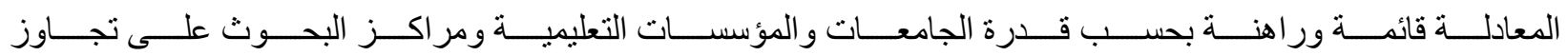

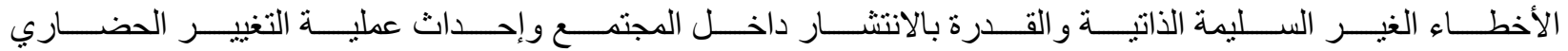
لتعزيز القيم الديمقر اطية.

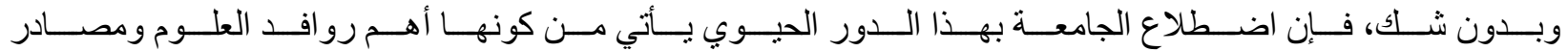

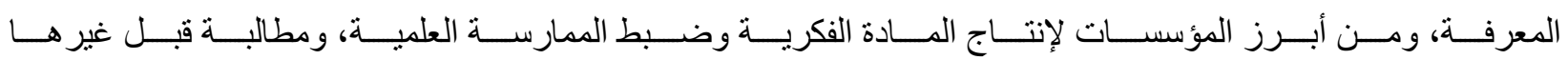

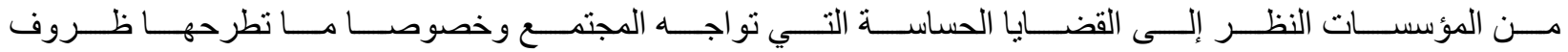

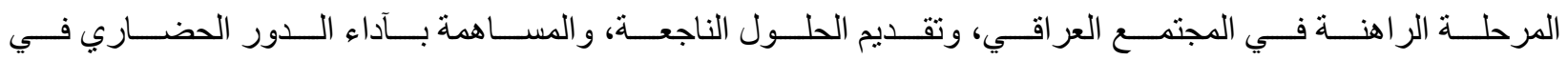

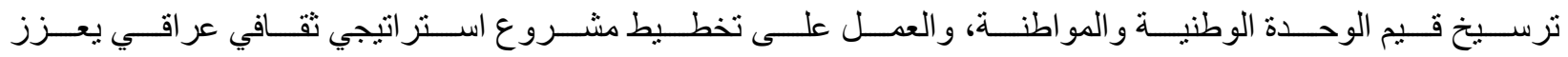




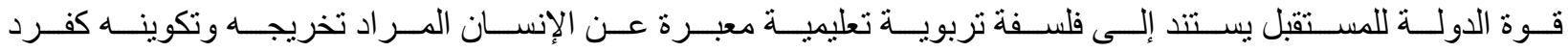
أو مجموع يؤسس لثقافة اللاعنف، و التسامح والاعتر اف بالآخر طائفيا، وعرقيا ومذهبياً . [10]

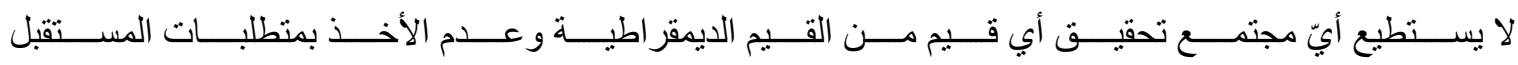

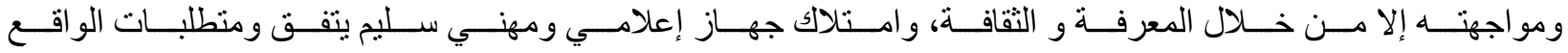

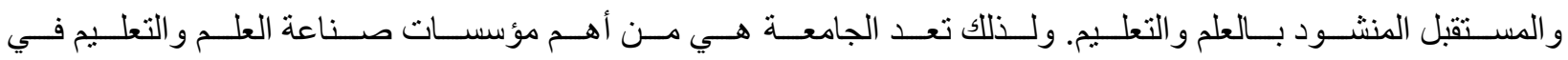

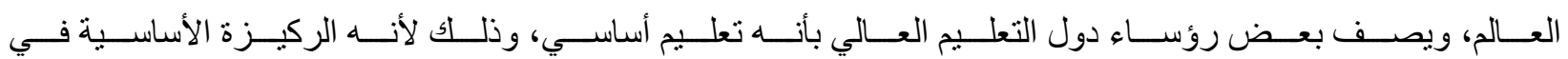

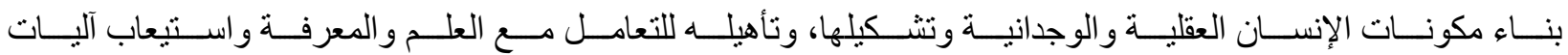
التقدم وتفهم لغة العصر.

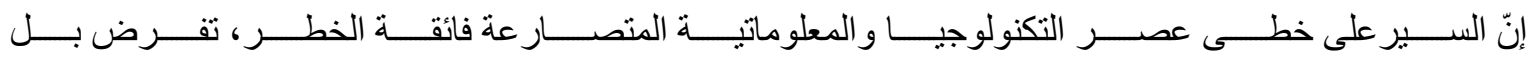

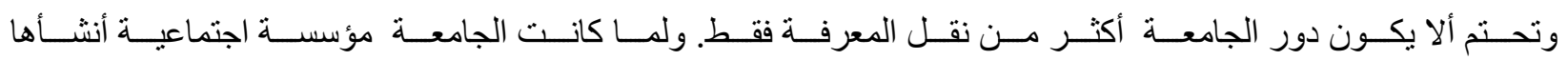

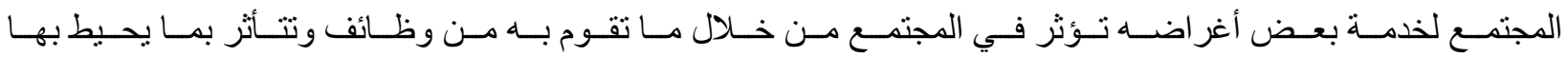

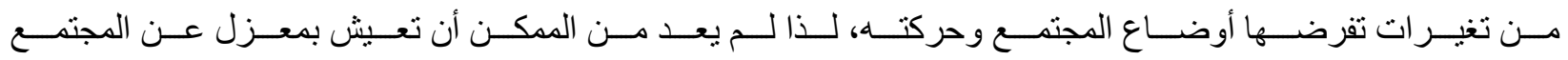

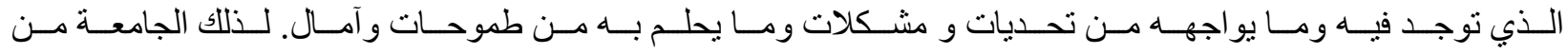
مؤسسات المهمة للنظام السياسي التي تعزز القيم الديمقر اطية وبناء المجتمع وفق أسس سليمة. 


\section{قائمة المصادر والمراجع:}

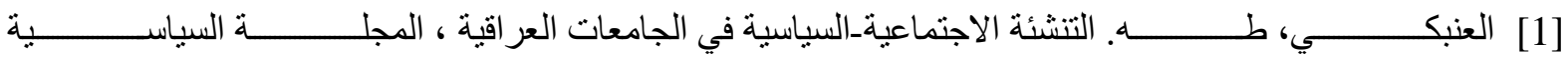
و الدولية،جامعة المستتصرية، بغداد، ع 14 (2010).

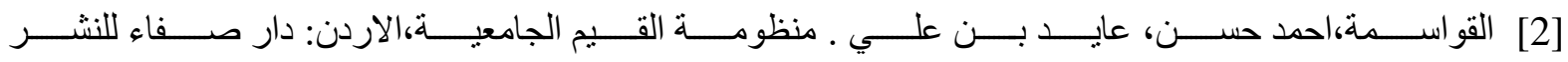
والتوزيع ،(2015).

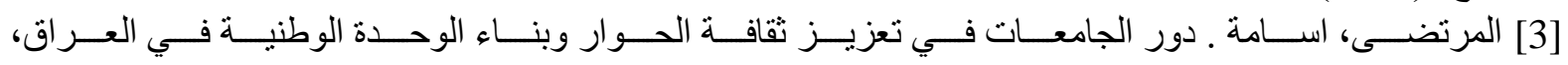

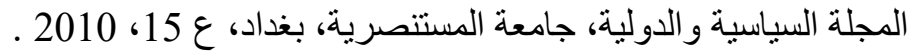

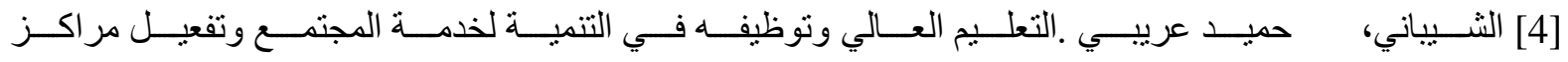

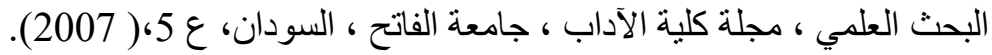

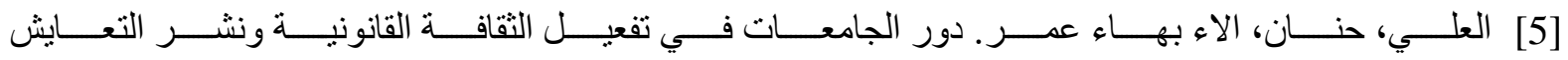

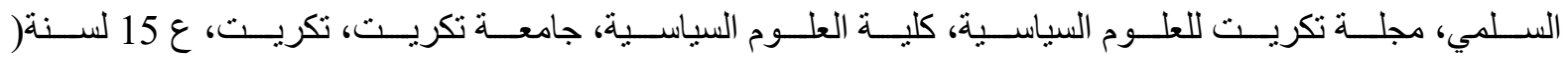
. (2018

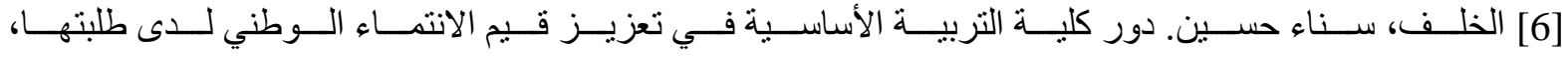

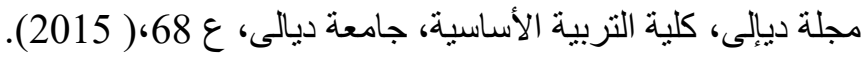

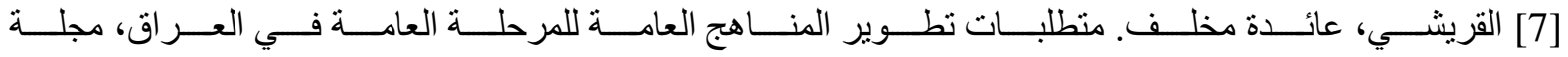

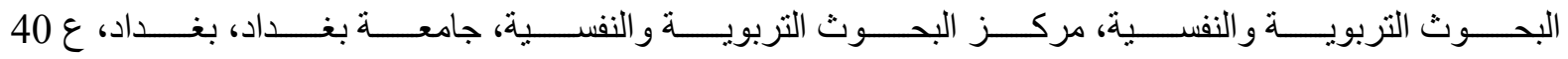

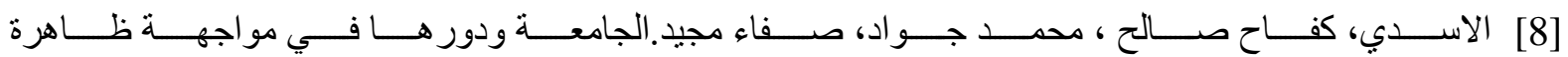

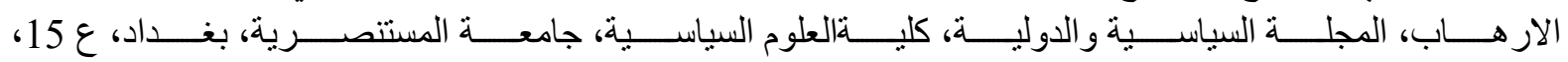

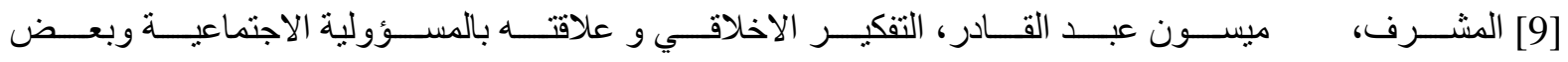

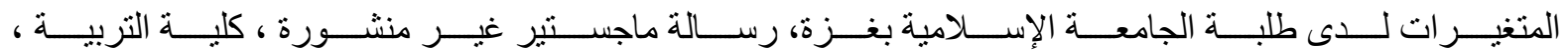
جامعة غزة، فلسطين، (1009) (2009).

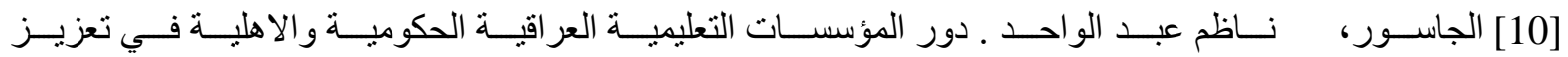

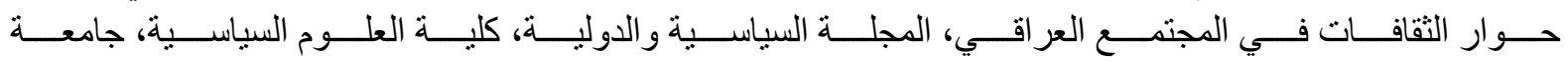
المستتصرية، ع 14، (2010). 